\title{
Mirjana Morokvasic
}

\section{Transnational mobilities and gender in Europe}

Keywords: transnational migrations and mobility, Europe, gender

\section{Introduction: migrant transnationalism}

Freedom of circulation within the EU has made the borders inside the EU space less important for citizens, for those who have a legal status or come from visa-free countries. For others, the controls have tightened and most have to rely on different economic, cultural and other networks capable of circumventing the restrictive border-management regimes.

In this text I will highlight the experiences of migrants who use borders and mobility as a resource in order to improve their social, political and economic condition.

The transnational perspective in migration research identified the phenomena of double and multiple belonging and creation of social spaces linking migrants (Glick Schiller et al., 1992; Portes 1996, 1999, 2001; Faist, 2000; Vertovec 2009). It challenged the static view of migration as a one-way movement from one location to another and helped rediscover and reappraise multiple historical examples of transnational practices among migrants which remained invisible, incompatible with the dominant integrationist/assimilationist wisdom in migration research, with little understanding for double and multiple allegiances.

European scholars have both adopted and adapted the transnational perspective, while producing a myriad of related conceptualisations (diasporas, mobilities, circulations, circulatory territories), trying to capture the changing realities of the re-composed migration landscape of the continent (Bauböck, 1991; Clifford, 1994; Faist, 2000; Faist et al., 2013, Ma Mung, 1999; Kastoryano, 2000; Morokvasic, 1992, 1999, 2004; Peraldi, 2001; Potot, 2005; Wallace, Stola, 2001; Weber, 2007; Riccio, 2001; Morawska, 2003; Nedelcu, 2009; Ambrosini, 2008). The pioneering research by Alain Tarrius $(1992,2013)$ on transmigrants and "circulatory territories" mobilized and inspired researchers mainly in southern Europe and the francophone world.

Criticisms notwithstanding (Vertovec, 2009), one has to recognize the heuristic value of the transnationalist perspective. It captures the complexity of phenomena 
related to migration and the post-migratory experience in the world characterised by the expansion of low cost transport, increased interdependencies, and global interconnectedness. For a long time, for instance, maintaining contacts with and orientation towards the country of origin was believed to have a negative impact on immigrants' opportunities and to jeopardize their upward mobility. The transnationalist approach suggests the opposite: that the cultivation of networks with the country of origin can be a valuable resource.

There is a vast variety of transnational migration experiences and many typologies provide useful lenses for understanding them (Portes, 1999; Faist, 2000; Ambrosini, 2008; Vertovec, 2009). The overwhelming focus on the nation-state as a frame, on durability and sustainability of transnational links over time leaves however little room to capture transnational practices which are not a strategy of already settled immigrants, but of mobile individuals who "migrate in order to remain in their place of residence" (Morokvasic, 1999) or to examine the lasting mobilities of those for whom the options of immigration and settlement are neither accessible nor desirable goals.

In this paper I look beyond the frame of the nation state at trajectories of migrants whose focal point remains their place of origin and who are on the move for purposes of work and trade, in order to improve their condition at home (Kuzma, 2012; Morokvasic, 1999; Wallace, Stola, 2001).

Using examples from some of my previous work and other studies I will focus on mobility whereby migrants shift the various boundaries of belonging, transgress national boundaries but also gender norms as well as blurring the lines of occupational boundaries. They all to a different degree develop a transnational habitus and their transnational practices are gendered.

\section{Shifting the boundaries of ethnicity}

The way people practice border-crossing depends on the social and political context and their positioning in it relative to class, gender, migrancy. Some can ignore borders, for others they represent challenging obstacles.

Legal status and the state of origin are essential in discriminating between those who can and others who cannot cross a border, those who can have free access to the labour market and others who need a work permit, or have no other option but to remain undocumented. Therefore, state policies remain important for the formation of migrants' transnational circuits, but migrants' own networking and market forces also regulate and shape their practices. States cannot eradicate transnational migration phenomena, but they can make coming and going unattractive by raising taxes and 
increasing transport prices. They can make it more or less difficult by tightening or loosening their visa regimes or access to citizenship, or by imposing a restrictive definition of a family (excluding children above certain age or accepting only biological, nuclear family) or by extending waiting periods for family reunification or residency.

Social knowledge about border-crossing is unevenly distributed, and reliance on "gatekeepers" and migration brokers, either among the previously established personal networks or among professional smugglers or traffickers, becomes unavoidable for many border crossers, especially as border-management regimes tighten up.

Therefore, transnational relations between different social places in different countries are often initiated, shaped and sustained by those in possession of a legal and stable status. Shifting boundaries of group membership and identity markers of belonging, rendering them negotiable according to a situation, may facilitate transborder objectives and functioning.

The modification of borders (as with the German reunification in 1990 or with each EU enlargement) has both unified and fractured the spaces of regional cooperation in South, East and Central Europe and the Balkans, encouraging the practice of ethnic preference, whereby those who can claim a common origin with their target EU country obtain preferential treatment. Considered as "repatriation" or "return to the homeland", the migration of ethnic Germans to Germany was strongly supported by the FRG during the Cold War: from 1950 to 1990 the FRG received close to 2.5 million ethnic Germans, more than half of them originating from Poland. So when Poland liberalized its passport legislation in 1988, more than one million German Poles already residing in the FRG constituted an important base for the newcomers. As settled residents with a stable status and often as German citizens, they served as intermediaries between the newcomers and German society as employers, landlords and interpreters. Dual citizenship opened up opportunities on both sides of the border for their businesses: for instance, as Germans they had access to the EU enterprise creation schemes for the unemployed, and as Poles they could rely on production facilities and cheap labour thanks to their Polish networks across the border in Poland.

Germans from Transylvania (Saxons) who left Romania permanently before 1989 (which under the Ceausescu regime was the only option) initiated circulation from Germany to Rumania in the 1990s, but also created opportunities for nonethnic German Romanian migrants seeking work. Bénédicte Michalon (2003) demonstrates how the Saxons, mobilizing ethnicity and relying on pre-existing networks engaged in migration conceptualized as a "permanent return to the home 
country", actually produced diverse migration dynamics, including circulation. Their networking structures expanded to incorporate non-Saxon Romanians for the purpose of work in Germany or elsewhere in the Schengen area. Many Romanian Gypsies also migrated in this way, first heading to Germany before moving on to other European countries, developing cross-border networks and knowledge of institutions (Reyniers, 1996).

In contrast, in a situation where restrictions to mobility persisted after 1990 as in the case of Albanians heading to Greece, the border and the activities related to border-crossing became a resource that only certain groups of people could use (De Rapper, Sintès, 2006). In a situation where doors selectively open, when speaking Greek and being Christian orthodox increases migration opportunities, ethnic markers and religious belonging become a matter of negotiation. People find various means to claim Greek ancestry and religion, such as changing names, adding a second, Christian name to the Muslim one or marrying a Greek as some women did enabling the rest of their Albanian family to move into the border region.

\section{Migratory capital: gendered 'settling in mobility'}

Mobility has a specific significance for women. In many societies obstacles and restrictions to women's mobility still persist. Historically they have been associated with immobility and passivity, for a long time invisible or regarded as dependents rather than migrants in their own right, their migration tied to that of men. And yet the capacity to be mobile is sometimes more easily available to women than to men because of specific demand (especially in the domestic and care sectors). They may become primo-migrants, pioneering migration chains.

Women are therefore exposed to contradictory pressures, relating to their role as breadwinners (requiring emigration and absence) and as family carers (habitually iplying a physical presence near those they care for). They are typically blamed for the social costs of migration and disruption of a gender order, and can be targets of moral stigmatization (Ogaya, 2004; Keough, 2006; Morokvasic, 2007)

While for both men and women the crossing of borders can lead to more autonomy and the challenging of established gender norms and intergenerational hierarchies, it can also lead to new dependencies and reinforce existing gender boundaries and hierarchies.

In the following examples of cross border mobility in three different occupations, it will be shown how gender norms are challenged, apparently preserved, but also renegotiated. 
Incessant mobility can last over a long period of migrants' lives. Rather than trying to immigrate and settle in the target country, some tend to settle in mobility, staying mobile as long as they can in order to improve or maintain the quality of life at home (Cyrus, 2008; Morokvasic, 1999; Potot, 2005). Migration thus becomes their lifestyle, a 'career'. Paradoxically, their leaving home and going away becomes a strategy for staying at home and an alternative to emigration.

Their resource is their "know-how-to-move" (Tarrius, 1992) and their capacity to stay mobile (Irek, 1998; Morokvasic, 2004). It is an important dimension of their social capital (Bourdieu, Wacquant, 1992) if and when they can mobilize it. Access to a stable status (residence, citizenship, regularisation) can be just one aspect of it, rather than a search for permanent settlement (Razy, Baby-Collin, 2011). It provides for easier mobility including other members of the network: for example, Zahra's regularisation in France through marriage creates a further link to her home country enabling her to travel and to bring over her sister (Tarrius et al., 2013, 169).

The people on the move from Central and Eastern Europe capitalize either on their own previous experience of shuttle migration in the socialist period when they acquired a know-how-to-travel, a migratory capital (Irek, 1998; Morawska, 2003), or they join the existing networks, learn from and rapidly emulate the experience of others (Michalon, 2003). Polish "guest workers" in the German Democratic Republic and Russian military personnel were among the precursors in "suitcase trading" because they could move during a period when others could not.

Commuting to improve the level of living at home belongs to a way of life among families in an agricultural region in Romania. One or more members leave at regular intervals for Andalusia, Spain, where there is a demand for cheap, flexible, Eastern European labourers, welcomed by the local employers as adaptable, undemanding, and non-visible (Potot, 2005). Like Poles, Romanians acquired a certain kind of a mobility know-how participating in various labour export schemes concluded under the Ceausescu regime with the FRG, Libya, Egypt and Iraq.

During their itineraries, migrants rely on transnational networks of "friends" built on the common experiences and interests of those who have worked in the target country, who travel the same distances, invest in the same spaces and deal with the same intermediaries (travel agents, guides, recruiters, lodgers, train attendants, border guards, customs officers, shop owners). The strength of these ties lies in their functionality and the effectiveness of the activities that migrants engage in rather than in a community-related frame (Morokvasic, 1999; Peraldi, 2001). They are instrumental acquaintanceships based on trust and reciprocity rather than on kin, connecting members of different groups beyond ethnicity boundaries into networks of information and assistance. 


\section{'Self-managed' rotation in domestic sector and care}

First I worked three years in order to be able to finish building our house. Now, I have been working for three further years to maintain that house, because the heating and the rest are enormously costly and my husband is unemployed. One could never pay that without my Belgian salary. That is my life: six years of cleaning jobs in exchange for a beautiful house in which I live only for one or two months a year. (Polish migrant, Brussels-Podlasie, Kuzma, 2012).

This is an example of people for whom incessant mobility is their career over a long period of their lives. The issues of integration, segmented assimilation or return do not capture their experience and projects: they do not 'integrate' in a specific national context and return has no significance for those who think of themselves as having never left.

Polish women I observed in Germany and Poland create a transnational migratory space in which they try to optimise the opportunities and minimise the obstacles relative to their reproductive and productive work. They set up a system of rotation so that they can go home at regular intervals, while their female substitutes take up their cleaning or other jobs in Germany during that time. They are usually a group of four to five women sharing both employers and housing (thus reducing reduces the cost incurred by double residence). The regularity of their commuting seems to be determined by their care for the family remaining in Poland.

As for their own families, they rely on a network of family members or paid caregivers (Cyrus, 2008; Kuzma, 2012). They improvise new caring arrangements different from the typical joint, simultaneous arrangements functioning on a daily basis, closely bound spatially and temporarily, which are constructed as a norm and which transnational mothers and carers contribute to maintain in the households of their employers (Morokvasic, 2004). In the case of the men who work mainly in construction or in agriculture, commuting takes place at less regular intervals and is determined by the seasonal nature of their jobs.

In addition to enabling women to have a transnational, double presence that combines their caring lives "here" and "there", the rotation system yields other opportunities for agency. Firstly, women avoid being trapped in an institutionalized form of dependency on a single employer (Morokvasic, 1999; Hess, 2005). Secondly, the constant mobility enables women to avoid the drawbacks of illegal status, or to avoid being illegal altogether as long as their sojourn takes place within the threemonth visa-free period for tourists. Thirdly, in a sector where upward mobility is 
almost impossible and where most of the Central and Eastern European women are declassed and de-skilled, some of them draw on their accumulated social knowledge and their experience in a rotation system and eventually develop into a small migrationmanagement business as brokers: the contact addresses and job offers are marketable because without an address, a telephone and a "recommendation" of a trustworthy person, it is impossible for a newcomer to get a job (Kuzma, 2012).

The leading "broker" may be a German-Polish connection - a woman who has a stable status as a German citizen or as a long-term resident (Münst, 2008). She starts using her own rotation group, her established local connections, and builds up a new network.

Gender order seems resistant to change in migration, even in situations of apparent reversal, when women become main breadwinners. While circulatory migration brings to both men and women more autonomy and opportunities in using the acquired social capital within a broader migratory space, back in the home country the gender order reasserts itself and women have fewer opportunities to make use of their success, confronted with moral stigmatization (Potot, 2005).

Whereas the presence of migrant women in personal services contributes to increasing equal opportunities in the labour market between local middle class women and men, it enhances inequalities among women and in the same time the gender division of labour in the household remains unquestioned (Oso, 2003; Lutz, 2008). Especially when employment is considered as a "family obligation" for women, it is not likely to bring about changes in male-female relationships (Kalwa, 2008).

\section{Mobile entrepreneurs: a comparison}

Trading is another occupation of the people on the move. Among Eastern Europeans it involves mixed groups: gender and intergenerational role attribution during trips provide a family-like profile to the group, an inconspicuous one because it appears more private than professional. Trading further relies on unquestioned gender relationships and hierarchies which assign to women and men different positions and related expectations. Men act as group leaders and protectors, while women are assigned the task of negotiators. They are in charge of the transport of more sensitive goods and may be expected to make use of their charms to attract customers or deal with customs officers (Irek, 1998; Karamustafa, 2001; Peraldi, 2001).

The circulation in the Euro-Mediterranean region involves other groups of people beside Eastern Europeans, mostly from North Africa. Increasingly feminised, presentday flows from that region do not correspond any more to former male-dominated 
patterns where women stay behind or later follow as part of a family reunion process. With the exception of female traders from West Africa, female traders are a rather new development in North Africa. Now in the majority, they have not only invaded an originally completely male sphere, but they also go out into a public space to do the trading. Gaining autonomy for themselves and the social promotion of their family are the main incentives of such moves (Peraldi, 2001). Besides the changing patterns of migration and trading, the feminisation of the cross-border trading circuits also reflects the power that the newly performed mobility confers to women in societies which traditionally limited their mobility.

Being a woman becomes an advantage: crossing borders, confronting obstacles (visas, customs officers) can be easier for women. Feminine attributes and dress are (like with women from the Eastern Europe) used as a tactic to cross borders and to smuggle some articles. North African women, for example, instrumentalise the veil which, as the 'instrument of the weak' confers a feeling of security enabling women to cross the boundaries into public space (Schmoll, 2005).

Their "know-how to circulate" differs between the rotation of Polish domestic workers and traders. The Polish function as a group, but travel individually and substitute each other at weekly or monthly intervals. The North Africans travel in groups: by having a socializing function for the newcomers as a social control, the group minimizes the risk of transgression of the gender code implied in geographic mobility.

Women in the world of men often have a male "protector": whereas among the Eastern Europeans the male protector regulates and manages the services - including sexual services - which some women of the group would provide as a part of trade negotiations (Irek, 1998), the protector of Tunisian women observes that their moral code is preserved and that they are not sexually assaulted (Schmoll, 2005).

\section{Sex work and entertainment}

Sex workers are primarily economic migrants, they tend to consider their work as a transitory gate opener to the EU labour markets, as swiftly remunerative activity, practiced because of the lack of alternatives or as an extension to other activities.

Sex work often implies mobility and circulation, either required by the work, by entry regulations or by family and other commitments at home (Thiévent, 2010). Postcommunist trading trips also involved occasional prostitution. Housewives, badly paid civil servants, school-girls and students resorted to it in order to increase their own travel gains or the likelihood of a successful trade transaction. Some women travelled 
across the border exclusively as weekend prostitutes, which enabled them to keep their jobs at home and double or triple their salaries in just one trip (Morawska, 2003). Engaging in prostitution is considered as a quick way to make ends meet for single mothers without job or to get a starting capital for a project at home (Karamustafa, 2001), whether under pressure from or in agreement with the family.

Our trans-European study of migrant women in the labour market shows that women also move into or reenter prostitution from other low paid and undesirable jobs, performed in degrading and humiliating conditions for low pay, like domestic work or agriculture. Carmen, from Columbia, earns well and can afford to shuttle between Germany, where she works for periods of two months, and Spain, where she is meanwhile a citizen, and where she spends time with her family. Masza and Viola commute between Krakow and their home towns in Ukraine, whereas Lilia, also a Ukrainian, worked as a dancer in the Middle East and Italy before coming to Slovenia (Catarino, Morokvasic-Müller, 2013).

Sex workers, who remain independent and in control of their mobility, use the accumulated capital to improve their condition by setting up businesses at home.

Others are obliged to rely on a protector or a smuggler in order to cross borders (Lazaroiou, Ulrich, 2003). The risk is being trapped in the circuit of forced sexual nomadism, being rotated by pimps from one European city to another within a system in which gender power hierarchies are exacerbated. Women are usually aware of the limits of promises of a "decent and well-paid work", but are also aware that this is their only way into the European labour market.

\section{Concluding remarks}

\section{Resistance to the nation state-based logic of exclusion and segregation}

In this presentation the focus has been on those who can build on their spatial mobility and know-how and successfully use the opportunity structures made available to them in the process of changing border management regimes. Mobility as a strategy can be empowering, a resource, a tool for social innovation and agency, if it is under the migrants' own control. Women and men rely on spatial mobility as a resource to mitigate risks by transnationalizing them. Individual strategies can become a collective resource, social knowledge about border crossing being shared by the members of the network, beyond its ethnic boundaries (as in the case of Saxons or numerous mobility managers during the trading trips). When the Greek state closes the borders, 
the reinforced ethnic heterogeneity becomes a resource, a useful migratory capital for some of the potential border crossers or their clients on the Albanian side.

Migrants are acting in the context of globalization which tends to eliminate barriers to the circulation of capital and goods while selectively maintaining or even erecting new barriers to the circulation of people. They are not abolishing borders, but trying to circumvent them and even use them as a resource. They contribute to "democratizing borders" as Etienne Balibar $(2003,170)$ would call such resistance to the state logic of exclusion and segregation.

\section{Gender orders unbound?}

Women from Eastern Europe innovate transnationally in the organization of their work and private life: the rotation system enables them a transnational dual presence that combines life here and there. In the domestic and caretaking sectors, where women are predominant and where upward mobility is practically impossible, they also find niches for business creation.

Being a woman may sometimes be advantageous when engaging in migration. Tunisian women go out into the public space and enter a previously male-dominated sector (Schmoll, 2005). By acquiring material prosperity, women also become empowered to abandon unsatisfactory relationships at home or to impose more tolerant and egalitarian relationships with their partners. Those with families often mention that they find themselves able to renegotiate the division of labour in the household. They feel they have more respect and authority in decision making (Irek, 1998).

In a stigmatized activity as sex work, leading a transnational life, relying on mobility and crossing borders in order to maintain a balance between home and the workspace, is one of the ways of gaining autonomy, resisting exclusion and illegality and coming to terms with the stigma. Commuting between Ukraine-home and Poland-work or Spain-home and Germany-work enables women to keep their two lives separate making sure that their earnings as sex workers in the country of work contribute to their respectable social position as breadwinners in their families and in their home milieu (Catarino, Morokvasic-Müller, 2013).

And yet, the deep-rooted gender order is not, at least not openly challenged. Gender norms and expectations often remain unquestioned in migration, even in situations of apparent reversal, when women become main breadwinners. The cultural ideals about men as economic providers often prevail, shaping both behaviours and outcomes. 


\section{References}

Ambrosini, M., Séparées et réunies: familles migrantes et liens transnationaux, Revue européenne des migrations internationales 24 (3), 2008, p. 79-106

Balibar, E., L'Europe, l'Amérique, la guerre. Réflexions sur la médiation européenne, Paris 2003.

Bauböck, R., Transnational citizenship. Membership and rights in international migration, Aldershot 1994.

Bourdieu, P., Wacquant, L. J. D., Réponses, Paris 1992.

Catarino, C., Morokvasic-Muller, M., Blurred lines: Policies and experience of migrant women in prostitution and entertainment, in: Paradoxes of Integration. Female Migrants in Europe (eds. Anthias F. et al.), Dordrecht, Heidelberg, New York, London 2013, p. 153-172.

Clifford, J., Diasporas, Cultural Anthropology 9 (3), 1994, p. 302-338.

Cyrus, N., Managing a mobile life: changing attitudes among illegally employed Polish household workers, in: Migration and mobility in an enlarged Europe. A gender Perspective (eds. Metz-Göckel, S. et al.), Opladen 2008, p. 179-202.

De Rapper, G., Sintès, P., Composer avec le risque: la frontière sud de l'Albanie entre politique des Etats et solidarités locales, Revue d'études comparatives est-ouest 37 (4), 2006, p. 243-271.

Faist, T., The volume and dynamics of international migration and transnational spaces, Oxford 2000.

Faist, T. et al., Transnational migration, Cambridge 2013.

Glick Schiller, N. et al., Towards a transnational perspectives on migration, New York 1992.

Hess, S., Au Pair als transnationale Migrationstrategie von Frauen aus Osteuropa, Wiesbaden 2005.

Irek, M., Der Schmugglerzug. Warschau-Berlin-Warschau. Materialien einer Feldforschung, Berlin 1998, p. 122.

Kalwa, D., Commuting between private lives, in: Migration and mobility in an enlarged Europe. A gender Perspective (eds. Metz-Göckel, S. et al.), Opladen 2008, p. 121-140.

Karamustafa, G., Objects of desire - A suitcase trade (100 Dollars limit), in: Geschlecht und Globalisierung. Ein kulturwissenschaftlicher Streifzug durch transnationale Räume (eds. Hess, S. et al.), Konigstein/Taunus 2001, p. 166-180.

Kastoryano, R., Immigration, transnational community and citizenship, International Journal of Social Sciences 165, 2000, p. 353-361. 
Keough, L. J., Globalizing "Postsocialism": mobile mothers and neoliberalism on the margins of Europe, Anthropological Quarterly 79 (3), 2006, p. 431-461.

Kuzma, E., Emergence d'une communauté transnationale dans l'espace migratoire européen. Analyse de la migration polonaise à Bruxelles (2002-2009). Doctoral thesis, Université Libre de Bruxelles 2012, p. 456.

Lazaroiu, S., Ulrich, L., Le trafic des femmes: une perspective sociologique, in: Visibles mais peu nombreux. Les circulations migratoires roumaines (ed. Diminescu, D.), Paris 2003, p. 265-300.

Lutz, H., Migration and Domestic Work. A European perspective on a Global Theme, Aldershot 2008, p. 215.

Ma Mung E., La dispersion comme ressource, Cultures \& Conflits, 33-34, 1999, http:// conflits.revues.org/46 [10. 10. 2013].

Michalon, B., Circuler entre Roumanie et Allemagne. Les Saxons de Transylvanie, de l'émigration ethnique au va-et-vient, Balkanologie VII (1), 2003, p. 19-42.

Morawska, E., Immigrant transnationalism and assimilation : a variety of combinations and the analytic strategy it suggests, in: Toward Assimilation and Citizenship: Immigrants in Liberal nation-states (eds. Joppke, C., Morawska, E.), Basingstoke 2003, p. 133-176.

Morokvasic, M., La mobilité transnationale comme ressource: le cas des migrants de l'Europe de l'Est, Cultures \& Conflits 33-34, 1999, http://conflits.revues.org/46 [10. 10. 2013].

Morokvasic, M., Settled in Mobility: Engendering Post-wall Migration in Europe, Feminist Review 77 (1), 2004, p. 7-25.

Morokvasic, M., Une migration pendulaire: les Polonais en Allemagne, Hommes et Migrations 1155, 1992, p. 31-37

Morokvasic, M., Yougoslaves, in: L'Argent des immigrés (eds. Tapinos, G., Garson, J. P.), Paris 1981, p. 267-299.

Münst, A. S., Social capital in migration processes of Polish undocumented care- and household workers, in: Migration and mobility in an enlarged Europe. A gender Perspective (eds. Metz-Gèockel, S., Morokvasic, M., Senganata Mèunst, A.), Opladen 2008, p. 203-224.

Nedelcu, M., Le migrant online, Paris 2009, p. 187.

Ogaya, C., Social Discourses on Filipino women Migrants, Feminist Review 77, 2004, p. 180-182.

Oso, L., The new migratory space in southern europe: the case of sex workers in Spain, in: Crossing Borders and Shifting Boundaries. Gender on the Move (eds. Morokvasic, M. et al.), Opladen 2003, p. 207-227. 
Peraldi, M., L'esprit de bazar. Mobilités transnationales maghrebines et sociétés métropolitaines. Les routes d'Istanboul, in: Cabas et contenaires. Activités marchandes informelles et réseaux migrants transfrontaliers (eds. Peraldi, M. et al.), Paris 2001, p. 329-361.

Portes, A., Conclusion: Toward a new world - the origins and effects of transnational activities, Ethnic and Racial Studies 22 (2), 1999, p. 217-237.

Portes, A., Global villagers: The rise of transnational communities, American Prospect 25, 1996, p. 74-77.

Portes, A., Introduction: The debates and significance of immigrant transnationalism, Global Networks 1 (3), 2001, p. 181-193.

Potot, S., La place des femmes dans les réseaux migrants roumains, Revue européenne des migrations internationales 21 (1), 2005, p. 243-58.

Razy, E., Baby-Collin V., La famille transntionale dans tous ses états, Autrepart 57-58 (1), 2011, p. 7-22.

Reyniers, A., Migrations tsiganes de Roumanie, in: Visibles mais peu nombreux. Les circulations migratoires roumaines (ed. Diminescu, D.), Paris 2003, p. 51-63.

Riccio, B., From 'ethnic group' to 'transnational community'? Senegalese migrants' ambivalent experiences and multiple trajectories, Journal of Ethnic and Migration Studies 27 (4), 2001, p. 583-599.

Schmoll, C., Pratiques spatiales transnationales et stratégies de mobilité des commerçantes tunisiennes, Revue européenne des migrations internationales 21 (1), 2005, p. 131-154.

Tarrius, A. et al. Transmigrants et nouveaux étrangers, Toulouse 2013, p. 200.

Tarrius, A., Les fourmis d'Europe. Migrants riches, migrants pauvres et nouvelles villes internationales, Paris 1992, p. 207.

Thiévent, R., Temporal dimensions of cabaret dancers' circular migration to Switzerland, in: New sociologies of sex work (eds. Kingston, S., Hardy, K.), Aldershot 2010, p. 149-165.

Vertovec, S. Transnationalism, London 2009.

Wallace, C. and Stola, D., Introduction: Patterns of migration in Central Europe, in: Patterns of migration in Central Europe (eds. Wallace, C., Stola, D.), Houndmills 2001, p. 3-44.

Weber, S., Nouvelle Europe, nouvelles migrations. Frontières, intégration, mondialisation, Paris 2007. 


\section{Mirjana Morokvasic}

\section{Transnacionalnamobilnost in spol}

Ključne besede: transnacionalne migracije in mobilnost, Evropa, spol

Prispevek osvetljuje izkušnje migrantov kot socialnih inovatorjev, ki izumijo različne načine transnacionalnega življenja, izkoristijo meje in mobilnost kot vire za izboljšanje svojih socialnih, političnih in ekonomskih pogojev življenja ter tako od spodaj navzgor prispevajo k integrativnim procesom po vsej Evropi. Avtorica se prek empiričnih primerov iz lastnega raziskovalnega dela in primerov iz študij drugih osredotoči na mobilnost, pri kateri migranti premikajo meje različnih zamejevanj

pripadanja, ne upoštevajo nacionalnih meja, kršijo spolne norme in brišejo meje poklicev. 